\title{
EL PROBLEMA DE LA VIOLENCIA Y SU LIBERACIÓN EN EL PENSAMIENTO DE KRISHNAMURTI
}

\author{
MANUEL SUANCES MARCOS
}

UNED

\begin{abstract}
RESUMEN: La meta del pensamiento de Krishnamurti es la liberación humana. Y el primer reto de ésta es enfrentarse a ese núcleo de impulsos e instintos que el hombre comparte con el animal y que se resume en eso que llamamos violencia. Krishnamurti hace un profundo análisis de ésta poniendo de relieve sus raíces, formas, causas y naturaleza. Luego aborda la posibilidad de la liberación de la violencia alertando primero de las falsas salidas al problema. Y después, se centra en el verdadero camino de la erradicación de la violencia que es la visión directa, inteligente y comprensiva del fenómeno. Esta comprensión aporta una nueva energía que expulsa la violencia del espacio interior del alma.
\end{abstract}

PALABRAS CLAVE: Krishnamurti, violencia, odio, lucha, poder, egoísmo, observación, inteligencia, comprensión, energía.

\section{The problem of violence and its liberation in the Philosophy of Krishnamurti}

ABSTRACT: The aim of the thought of Krishnamurti is human freedom. The first challenge of it is to face the center point of instincts and stimulations that man shares with animals and that resumes that we call violence. Krishnamurti makes a deep analysis of this aim pointing out its roots, shapes, causes and nature. Then it centers its objetives in the possibility of avoiding violence advising of the erroneous solutions of the problem. After this, it is centered in the real way of the eradication of violence that is the direct way, intelligent and comprehensible. This comprehension offers a new energy that expels the violence of the inner space of the soul.

KEY WORDS: Krishnamurti, violence, hate, fight, power, selfisnesh, observation, intelligence, comprehension, energy.

\section{INTRODUCCIÓN}

Jiddu Krishnamurti (1895-1986) es un gigante espiritual de nuestro tiempo. Sus enseñanzas se extienden cada día más a lo largo y ancho del mundo. Tiene la habilidad de llegar a todo tipo de personas, sea cual sea su condición, porque utiliza un lenguaje sencillo e inteligible para cualquiera. Dentro de esa sencillez, se percibe la carga espiritual que transmite y es su vivencia y compromiso de liberar al ser humano. Él ha vivido hondamente esa experiencia y no ceja de trabajar por conseguirlo. Por toda su obra trascurre un halo de frescura y renovación.

Pero la liberación, tiene muchos aspectos complejos. Lo requiere así la sublime pero espesa condición humana. Y el primer reto que asume en ese proceso liberatorio es ayudar al hombre a enfrentarse a ese bagaje de instintos, pasiones e impulsos que comparte con los animales y que inclinan por naturaleza a la violencia. Es un descenso a los infiernos para liberar a ese cautivo que es el alma humana. Y comienza por los fondos más bajos de esa pasión como son los impulsos biológicos: odio, crueldad, ira, agresividad, lucha, etc. que tienen la violencia como denominador común. Es este un tema central que hoy día es foco muy importante de reflexión en todo el mundo, para llegar a una convivencia pacífica y en libertad. 
Así pues, afronta en primer lugar esa realidad biológica compartida con los animales y que tantas facetas tiene: la violencia. Bajo el denominador común de la palabra «violencia», Krishnamurti reúne un enjambre de sentimientos e impulsos de diversos perfiles, pero que comparten un núcleo común. Son el odio, la crueldad, la ira, envidia, agresividad, lucha, guerras, etc., con sus secuelas de destrucción. En torno al tema central de la violencia, irá esclareciendo los diversos matices de cada una de esas manifestaciones.

\section{Fenomenología de La Violencia: SU EXISTENCia E IMPLiCACiONES}

Krishnamurti, para abordar este tema, echa bien los cimientos pisando la tierra firme de la realidad, de los hechos. No se atiene a teorías o elaboraciones mentales sobre la violencia. Ésta, en el hombre, es un hecho incontrovertible:

«Intentamos comprender la violencia como un hecho, no como una idea, como un hecho que existe en el ser humano, que soy yo mismo. Y para abordar el problema, debo ser del todo vulnerable, estar abierto a él. Debo exponerme a mí mismo "no necesariamente exponerme a usted, porque podría no estar interesado", pero debo hallarme en un estado mental que exige ver el problema en toda su extensión, sin detenerme en ningún momento ni decir que no seguiré adelante» (Limpia tu mente, p. 63) ${ }^{1}$.

Este problema, como todos los demás problemas humanos, es muy complejo. Y conviene encararlo sin prejuicios ni posturas previas. Sin actitudes positivas o negativas. Somos violentos como individuos, como grupo, como colectividad. Por cualquier menudencia brota entre nosotros el odio, la agresividad, de palabra o de hecho. No hay proporción entre el pequeño incidente y la carga de agresión que suscita. ¿Por qué hacemos esto?

Después de todo, este es uno de nuestros principales problemas. Todo el mundo se halla atrapado en la violencia, en las guerras. La estructura misma de nuestra sociedad es competitiva y violenta. Para salir de este infierno, cada uno de nosotros hemos de liberarnos totalmente de la violencia. Pero antes de hablar de liberación es preciso medir bien el alcance de la violencia en nosotros. Es una realidad incontrovertible que exige conciencia del hecho antes que refugiarse en ideales que nos alivien:

«Es importante, pues, observar el hecho de que los seres humanos son extraordinariamente violentos, de que nuestra cultura, la sociedad en que vivimos, todo nuestro estilo de vida con su codicia, su envidia y su afán competitivo engendra inevitablemente violencia. Y más importante aún es darse cuenta de esta violencia dentro de uno mismo, percatarse realmente de lo que es, no de lo que debería ser, porque "lo que debería ser" es una ficción, un mito, un concepto romántico que todas las religiones y los idealistas han nutrido y explotado a través de los tiempos. ¿De qué sirve el ideal de la no violencia si estoy lleno de violencia? Por favor, jes muy importante que esto se comprenda!» (Conversaciones con estudiantes, pp. 129-130).

Hemos construido una sociedad que es violenta y nosotros, como seres humanos, somos violentos; el ambiente, la cultura en que vivimos, es resultado de nuestras luchas aterradoras.

Ante este panorama tan desolador, Krishnamurti está muy atento a nuestra reacción. ¿Desplazamos fuera de nosotros el problema allá, al mundo exterior, o está dentro

\footnotetext{
1 Las referencias bibliográficas completas aparecen al final del artículo.
} 
de nosotros? Si personalmente uno está libre de violencia se pregunta: ¿cómo puedo yo vivir en un mundo rebosante de brutalidad? ¿No me destruirán en cuanto aparezca? ¿Qué puedo hacer yo, que me siento frágil, ante esa ingente realidad opresora? Podrá decirse que, en un mundo así, es imposible no desarrollar un impulso al menos defensivo contra la violencia; pero esto sería también violencia. Parece imposible salir del atolladero. Si no atacas, si no te defiendes, te destruyen, te engullen. ¿Cómo salir de este atroz laberinto? Antes de adelantar soluciones, Krishnamurti dirá que el solo hecho de plantear la pregunta supone que no se vive apaciblemente. Pues quien ha erradicado la violencia no tendrá problemas. Pero hay mucho que recorrer antes de llegar a ver esto.

La violencia es un hecho enorme en extensión y profundidad. Krishnamurti apunta primero a la extensión. Hay violencia en todas partes. Empezando por la misma naturaleza: trátese de una tormenta eléctrica, de un animal salvaje que mata a otro o de un árbol que muere; la violencia está en cualquier lugar. La vida entera es violencia, en lo pequeño y en lo grande.

Esta extensión de la violencia afecta igualmente a gente con cultura y sin ella. A veces incluso, pueblos y hombres que se tildan de progresistas y educados son refinados en la expresión de su violencia:

«La violencia está en todas partes, tanto entre los altamente educados como entre los más primitivos, entre los intelectuales y entre los sentimentales. Ni la educación ni las religiones organizadas han sido capaces de amansar al hombre; por el contrario, han sido las responsables de las guerras, las torturas, los campos de concentración y la matanza de animales en la tierra y en el mar. Cuanto más progresa, más cruel parece volverse al hombre. La política se ha convertido en gangsterismo, un grupo contra otro grupo; el nacionalismo nos ha conducido a la guerra; hay guerras económicas, hay odios personales, hay violencia. El hombre no parece aprender nada de la experiencia y el conocimiento, y la violencia prosigue en todas sus formas» (Diario II, p. 77).

Después de un viaje a la India, Krishnamurti regresa a Brockwood, cerca de Londres; allí funciona una escuela por el fundada en la que se trata de educar a los jóvenes que viven en este mundo de violencia. Krishnamurti llega preocupado hasta la obsesión por la guerra de Vietnam, la dictadura comunista y la pobreza ingente de la India y de Sudamérica. Entonces, enfrenta a los jóvenes ante esa realidad, haciendo ver cómo ha de responder su educación a tal estado de cosas. Como buen educador, Krishnamurti teme que la generosidad y valentía juveniles sean engullidas por la ferocidad del mundo de los adultos:

«Ustedes son aun jóvenes, pero a media que crezcan se darán cuenta del infierno, de la gran desdicha que el hombre debe padecer interiormente por estar en constante batalla consigo mismo, con su mujer, con sus hijos, con sus vecinos, con sus dioses. Vive en medio del sufrimiento y la confusión, y no hay amor, ni benevolencia, ni generosidad, ni caridad. Una persona puede llevar el título de doctor junto a su nombre, o puede convertirse en un hombre de negocios con casas y automóviles, pero si carece de amor, de afecto, bondad, consideración, es realmente peor que un animal, porque contribuye a la existencia de un mundo destructivo como éste. Así es que deben conocer todas estas cosas mientras son jóvenes» (Krishnamurti y la educación, p. 69).

Krishnamurti intenta preparar a los jóvenes enseñándoles a pensar para que comprendan el problema de la violencia. Y tarde o temprano, más bien temprano, no tendrán más remedio que enfrentarse a la sociedad. Sólo les queda esta alternativa: la violencia o el enfrentamiento con la sociedad. Y la escuela puede ser un buen laboratorio de entrenamiento. 
Pues bien, visto cómo la violencia afecta a todo, Krishnamurti analiza por separado los dos grandes frentes de la violencia, el de fuera, o sea la sociedad, y el de dentro, es decir, el interior del hombre. Bien entendido que el más importante y origen de toda violencia es el segundo; por eso se detendrá mas en él. Pero ahora examina el frente externo, la sociedad, que es justamente la proyección del mundo interior humano. La sociedad es el resultado de la propia violencia del individuo.

La estructura de la sociedad es la misma en todas partes, ya sea en Europa, Asia o América. Sus diferencias no ocultan la realidad esencial. Y ésta es que cada uno de los individuos es la sociedad y la humanidad entera, o sea, lo total. No existe separación entre individuo y sociedad. Y, para producir un cambio esencial que erradique la violencia, tiene que haber antes una transformación del individuo. Esta es una constante en las enseñanzas de Krishnamurti. Entonces, el verdadero problema es si los seres humanos, tal como somos ahora, viviendo en esta sociedad con sus guerras, luchas, ambiciones y competitividad, podemos producir una transformación en nosotros:

«Al parecer, el hombre se ha comprometido con la guerra, con la violencia y esta violencia existe en todo el mundo, aunque en Asia y especialmente en la India "donde las ideologías florecen como hongos en un campo húmedo" hablan muchísimo de la no violencia. Nosotros, los seres humanos, estamos comprometidos con la violencia, con un modo de vida que conduce a la guerra, a una existencia dividida por religiones y nacionalidades en creencias, dogmas, rituales y prejuicios extraordinarios. El hombre se ha comprometido con este extraño patrón de existencia, condenando justificadamente una guerra y estando, sin embargo, dispuesto a participar en otra; él mismo es violento, brutal y agresivo, características que los antropólogos atribuyen a su herencia animal. Lo que los antropólogos y especialistas dicen significa, sin embargo, muy poco, porque podemos examinar y descubrir por nosotros mismos la naturaleza de nuestra propia violencia, lo brutales que somos con respecto a otro, no sólo verbalmente sino en nuestros pensamientos y en nuestros gestos"»(Conversaciones con estudiantes, pp. 125-126).

Por miles de años hemos aceptado un estilo de vida que conduce inevitablemente a la guerra, al enfrentamiento sistemático y no hemos sido capaces de cambiarlo. Los políticos han tratado de hacerlo y no lo han conseguido. Al contrario, vemos florecer la violencia en todos los ámbitos de la sociedad.

Pero Krishnamurti deja ya la sociedad como lugar de manifestación de la violencia, para afrontar su verdadero origen: el interior humano. Hay que comprender el proceso de la destrucción y la violencia no sólo en lo externo, sino en nosotros mismos. Si no lo comprendemos, si meramente nos rebelamos, repetiremos una y otra vez el mismo patrón, el de la violencia, Porque aunque los seres humanos sean exteriormente cultos y educados, en lo interno son violentos. No es real mirar el desorden y violencia de la sociedad como algo ajeno a uno:

«¿Percibe usted la violencia como un enorme peligro para el mundo? El mundo es usted. Hoy en día todo, en política y en los demás campos, se consigue mediante la violencia. Eso es todo lo que está ocurriendo... Por lo tanto para mi, como ser humano que forma parte del mundo, debe haber una transformación en mi mismo. ¿Comprenden? Yo soy el mundo, soy un ser humano total. Y uno de los aspectos de estos brutos seres humanos, es la violencia, la cual representa un enorme peligro» (Pedagogía de la libertad, pp. 67-68).

Por consiguiente, la problemática de la violencia del mundo es parte de nosotros mismos, no somos extraños a ella.

Una realidad de tanta envergadura como la violencia echa sus raíces en la materia biológica humana. Nacemos con una especie de cerebro animal. Esa es la causa fundamental de la violencia. Somos naturalmente violentos, a menos que podamos saltar 
fuera de ello. Es posible examinar el estado individual de la mente y descubrir que somos intrínsecamente violentos dentro de nosotros mismos, en la propia condición de la actividad mental:

«Hemos sido educados para ser violentos. Nuestra naturaleza animal y la actividad del cerebro humano, etc., son violentas y separativas; conocemos todo esto. Las actividades egocéntricas, el ser agresivo, el oponerse, el resistir, el afirmarse, todo eso contribuye a la violencia» (La conciencia fragmentada, p. 163).

Es cierto también que hay una parte en nosotros que repele la violencia. Pero ésta tiene mucho más raigambre que nuestra tendencia a repelerla. Por eso, bajo el barniz de la educación, de las buenas formas y de la creencia de que hemos superado la ira y la violencia, ésta late con todo su vigor en nuestro inconsciente.

Por último, en este apartado, Krishnamurti aborda esta cuestión. ¿Por qué prolifera tanto la violencia? ¿Tiene algún atractivo? ¿Trae compensaciones? ¿De qué tipo? Pues sí, tiene secretos atractivos que la hacen proliferar tanto. En primer lugar, produce un inconfesado placer. "A la mayoría de nosotros, la violencia nos causa placer, así como sentir desagrado por alguien, odiar a una raza o a un grupo de personas determinado o tener sentimientos hostiles hacia otros» (Limpia tu mente, p. 61). La violencia, como sus derivados, el odio y la envidia, producen placer, nos unen contra el común enemigo y por eso no pueden ser eliminados fácilmente.

En segundo lugar, la violencia y el odio nos infunden un sentimiento de poder y con él vamos tejiendo la estructura de la sociedad:

«Al ser violentos nos sentimos poderosos. Para usar una frase comercial: el odio rinde dividendos mayores y más rápidos. El individuo, a causa del odio que contiene dentro de sí y debido a su deseo de vengarse y de actuar violentamente, ha creado la estructura social que hoy existe. El mundo que nos rodea se halla en esta febril condición, a causa de la artera e intencional fuerza que contienen el odio y la violencia; a menos que nosotros estemos libres de odio, somos arrebatados con facilidad por la brutal corriente» (Obras completas, vol. III, El espejo de la relación, p. 226).

$\mathrm{Y}$ en tercer lugar, la ira y la violencia permiten deshogarnos, justificarnos y darnos importancia:

«La ira tiene la característica peculiar de aislar; al igual que el dolor, nos incomunica y, al menos de momento, cesa toda relación. La ira tiene la fuerza y vitalidad momentáneas de lo aislado. Hay en la ira una extraña desesperación, pues el aislamiento es desesperación. La ira de la desilusión, de los celos, de la voluntad de herir, proporciona un violento desahogo cuya satisfacción es en verdad una justificación de nosotros mismos. Sin algún tipo de actitud, ya sea de altivez o de humillación, ¿qué somos? Empleamos cualquier medio para darnos importancia, y la ira, al igual que el odio, es uno de los más fáciles de conseguirlo» (Reflexiones sobre el ser, p. 117).

En definitiva, la violencia es el resultado de causas psicológicas profundas que actúan como justificación de nuestros sentimientos y como defensa que encubre lo que realmente somos. Cuando volvemos sobre nosotros mismos y descubrimos cómo somos, nos enfurecemos por ello.

\section{Formas y CAUSAS DE LA VIOLENCIA}

Después de constatar y describir el hecho de la violencia, su universal y aplastante realidad, Krishnamurti se detiene ahora en desarrollar, aunque no con mucha extensión, 
el abanico de los diversos colores o formas de la violencia. Es un fenómeno que tiene infiltraciones de todo tipo. Se parece a un caleidoscopio en constante movimiento. Con diversos matices, intensidades y perfiles. Sin ser exhaustivo en la enumeración, da una razón de conjunto para ver el alcance raigambre del problema. La primera distinción que hace es la de la violencia física y psíquica:

«Violencia no es solamente matar a otra persona. Hay violencia cuando empleamos una palabra ofensiva, cuando hacemos un gesto para mandar a alguien a paseo, cuando obedecemos porque sentimos temor. Así, pues, la violencia no es tan sólo una carnicería organizada en nombre de Dios, de la sociedad o del país, sino que es algo mucho más sutil, más profundo, y el objeto de nuestra indagación es lo más profundo de la violencia.

Cuando uno dice ser indio, musulmán, cristiano, europeo o cualquier otra cosa, está cometiendo violencia. ¿Ve usted por qué es violento? Porque se está separando del resto de la humanidad. Cuando uno se separa por la creencia, la nacionalidad o la tradición, engendra violencia. Por eso un hombre que trata de comprender la violencia no pertenece a ningún país, a ninguna religión, a ningún partido político o sistema parcial. Lo que le interesa es la comprensión total de la humanidad» (Limpia tu mente, p. 64).

Pero una vez contemplada esa profusión, va delimitando campos. En primer lugar, la violencia física cuyo paradigma es la guerra. Ésta ha existido siempre desde la aparición del hombre. Se ha dado en todas las épocas y países. Es uno de los azotes más amenazadores de la supervivencia humana. Krishnamurti está preocupado hasta la obsesión por ella. Pero es evidente que en lo que más insiste es en detectar sus causas para erradicar esta lacra de la humanidad. Así se expresa respecto a las guerras actuales:

«Todos nosotros tenemos la culpa de que el horror actual continúe. Éste es el resultado externo de nuestra vida cotidiana basada en la codicia, la mala voluntad y la lujuria, nuestra vida cotidiana de competencia, afán adquisitivo y religiones especializadas. La culpa es de todos los que, entregándose a esto, han creado la terrible calamidad que padecemos. Debido a que somos nacionalistas, individualistas, irascibles, cada uno de nosotros está contribuyendo a este asesinato en masa. A ustedes les han enseñado cómo matar y morir, pero no cómo vivir. Si de todo corazón aborrecieran la matanza y la violencia en cualquiera de sus formas, encontrarían medios y arbitrios para vivir pacífica y creativamente. Si ése fuera el interés primero y fundamental de ustedes, investigarían cada causa, cada instinto que contribuye a la violencia, al odio, al asesinato en masa. ¿Están así, de todo corazón, interesados en detener las guerras? Si lo están, entonces deben erradicar en sí mismos las causas que los impulsan a la violencia y a matar por cualquier razón que sea. Si desean poner fin a la guerras, entonces debe tener lugar en ustedes una profunda revolución basada en la compasión y la tolerancia; en tal caso, en el pensamiento-sentimiento debe liberarse del patriotismo, de su identificación con cualquier clase de grupos, así como de la codicia y de aquellas causas que engendran enemistas» (Obras completas III, p. 328).

Este texto es lo suficientemente elocuente para poner de manifiesto el entramado de los diversos movimientos que confluyen en la aparición de las guerras. Afecta de lleno a la estructura biológica y social humana. Esto mismo lo corrobora una y otra vez de diversas maneras.

Krishnamurti expone un elenco de movimientos e impulsos que ahora trata de ir despejando y tratando en particular. La guerra es la expresión por autonomasia de la violencia física. Es una explosión de odio, ira y brutalidad. Pero ahora se detiene en las causas psicológicas que son el verdadero fogón donde nacen y se cultivan las posteriores formas de violencia. Y también aquí Krishnamurti es explícito en detalles y formas de violencia psicológica: 
«Pero, ¿cómo puede la mente liberarse ella misma de la violencia acumulada, la violencia refinada, la violencia auto-protectora, la violencia de la agresión, la violencia de la competencia, la violencia de tratar de ser alguien, la violencia de tratar de disciplinarse uno mismo conforme a un patrón, tratando de llegar a ser alguien, tratando de reprimirse y de intimidarse uno mismo, de embrutecerse, para ser no-violento ¿cómo puede la mente estar libre de todos estos tipos de violencia? (Más allá de la violencia, p. 72).

Pero en medio de esta proliferación de formas, Krishnamurti se detiene especialmente en algunas de ellas. Sobre todo en la incidencia que tienen la obediencia y la obligación en la génesis de la violencia. La violencia física no plantea dificultad. Es tan brutal que no admite matices y, por eso mismo, fácil de afrontar psicológicamente. Pero la violencia que suscita tener que obedecer es mucho más dañina y no da la cara. Queda rezagada ahí dentro, pero con una carga de agresividad tan intensa como invisible:

«Cuando yo le obedezco y reprimo lo que pienso, esa represión estallará un día. Así que existe la violencia física y la que es engendrada por la obediencia; la violencia de competir, de amoldarse. Cuando me amoldo a un patrón, soy violento. ¿Ve la conexión? Cuando vivo una vida fragmentada o sea, cuando pienso una cosa y digo otra, hago otra eso es fragmentación y eso también engendra violencia. Yo puedo ser muy tranquilo, gentil, hacer todo el trabajo que me piden que haga, pero ardo de cólera; eso indica que, por dentro, ha habido represión. De modo que la violencia no es sólo violencia física, es una cuestión muy compleja. Y si usted no ha pensado al respecto, cuando tenga que enfrentarse a la violencia reaccionará de la manera menos inteligente» (Principios del aprender, p. 223).

Bien es cierto que Krishnamurti se adelanta enseguida a aclarar lo que es la obediencia legítima y necesaria y la que es, por naturaleza, opresiva.

¿Cuál es entonces el criterio para discernir la obediencia legítima de la represora? El criterio del orden. Tiene que haber la inteligencia o el discernimiento para ver que cualquier movimiento hacia el desorden es violencia:

«¿Cómo, entonces, tendrá usted el discernimiento para ver dónde el obedecer no es violencia y dónde sí lo es? ¿Ve la diferencia? Yo acato, imito cuando conduzco por la derecha o la izquierda. En este país me pongo pantalones, pero cuando voy a la India visto un traje hindú "¿es eso una clase de amoldamiento? E internamente, ¿me amoldo a ser un hindú, a mi tradición, a mis creencias?” ¿no es violencia eso? ¿Dónde está, pues, la línea divisoria entre la violencia y el ver por uno mismo las circunstancias en que la libertad es orden? Toda violencia es desorden. No malentiendan lo que estoy expresando y no digan después: "Yo no quiero amoldarme", y vayan a hacer alguna tontería. Todo el mundo está envuelto en la violencia, en diferentes categorías de desorden» (Principios del aprender, p. 225).

El criterio queda pues claro: cumplir las leyes de tráfico o vestir de determinada manera en un país que tiene ciertas normas no es amoldarse; no hay violencia. Pero engullir de inmediato las tradiciones, creencias, etc... de ese país, eso sí es amoldamiento. Por consiguiente, el discernimiento lleva a ver que lo primero conduce al orden y lo segundo al desorden; por tanto a la violencia. En conclusión, tendré claro dónde está la verdadera libertad y dónde está el germen de la violencia. Así pues, es preciso vivir una vida con gran orden; en ella se comprende la obediencia y se ve cuándo es necesario amoldarse y cuándo no.

Krishnamurti analiza aquí con especial cuidado el sentido de la obediencia y la obligación para que no engendren violencia. El sentirse forzado a tener que hacer algo es violencia. Por eso el problema se dilucida en el discernimiento interno que debe haber antes de cumplir una ley u obligación. Si éstas no se acogen internamente de modo 
positivo, de poco servirá su cumplimiento exterior. Lo que les da sentido es la aquiescencia interna que proviene de haber visto el orden que lleva consigo cumplir esas normas. De lo contrario, todo será violencia por mucho que externamente no aparezca y se cumplan puntillosamente las normas.

Lo que se acaba de decir de la obediencia se puede también proyectar al campo de la cooperación o de trabajo en equipo. Uno no tiene que cooperar porque sea obligado por alguien o porque las circunstancias le obliguen. Ha de cooperar porque ama el trabajar juntos; porque eso induce al orden y a la expansión vital y fraterna.

Siguiendo el hilo de esta reflexión de los motivos de la violencia psicológica, Krishnamurti da especial importancia a uno: la creencia. Esto a nosotros nos resulta extraño. Pero él insiste en que las creencias establecidas engendran separación y división:

«¿Por qué desea usted creer en algo? ¿Por qué desea creer en la unidad de todos los seres humanos? "el hecho es que no estamos unidos"; ¿por qué desea creer en algo que no es un hecho? Existe toda esta cuestión de la creencia; solamente piense: usted tiene una creencia y el otro tiene la suya; y pelean y se matan uno al otro por una creencia.

¿Por qué tiene alguna creencia del todo? ¿Cree usted porque tiene miedo? ¿No? ¿Cree usted que el sol sale? "el hecho está ahí para ser visto, no tiene que creer en eso". La creencia es una forma de división y, por lo tanto, de violencia. Estar libre de la violencia implica estar libre de todo lo que el hombre ha impuesto a otro hombre: la creencia, el dogma, los rituales, mi país y su país, su dios y mi dios, mi opinión, su opinión, mi ideal. Todo eso ayuda a dividir a los seres humanos y, por lo tanto, a engendrar violencia. Y a pesar de que las religiones organizadas han predicado la unidad del género humano, cada religión cree que es muy superior a las otras» (Más allá de la violencia, p. 81).

Este enfoque de las creencias es un punto especialmente álgido en Krishnamurti. Levantó muchas ampollas. Y creó muchas dificultades. Tanto mayores cuanto más firme se mantenía en esta posición. Será otro el momento de abordar en profundidad esta cuestión tan decisiva. Baste por el momento indicar que Krishnamurti no es un delator o iconoclasta de las creencias. Pero sí decir que ha tenido un especial tacto y sensibilidad para discernir cuándo las creencias son meras proyecciones antropológicas de los intereses humanos y cuándo son un camino expedito hacia lo eterno, lo sublime y lo intemporal. El espectáculo de las guerras generadas por las creencias es algo que le escuece demasiado y le ha llevado hasta el final del problema.

\section{Naturaleza y Raíces de la violencia}

Hasta ahora, Krishnamurti, ha dibujado un amplio panorama de las diversas formas de violencia; de sus causas y desastrosas consecuencias. Pero ha sido como sobrevolar por un ancho espacio relativamente homogéneo. Llega la hora de aterrizar. Es decir, tomar la violencia de cara, escrutarla en su esencia y buscar sus profundas raíces. Mientras no se haga esto, estaremos dando vueltas sin saber a fondo con qué realidad nos las habemos. Y esta es la tarea que acomete ahora ¿cuál es el núcleo interno de la violencia? Esa realidad última que comparten las manifestaciones a pesar de su pluralidad y diferencia? Poco importa ahora especular sobre si la violencia es algo innato o es resultado de la herencia racial y social. El hecho es que ahí está en toda su lozanía después de miles y miles de años y esfuerzos por erradicarla.

¿Qué es en el fondo la violencia? ¿Cuál es su esencia? La idea central de Krishnamurti es que la violencia es «violar» algo, imponerse sobre algo: 
"Consideremos la imposición primero, violar "lo que es". Soy celoso e impongo sobre eso la idea de no ser celoso: "no debo ser celoso". La imposición, el violar "lo que es", constituye violencia. Comenzaremos poco a poco, y quizás en esa única frase podamos cubrir la cosa completa. "Lo que es" está siempre en movimiento, no es estático. Lo violo al imponerle algo que creo "debería ser"» (El vuelo del águila, p. 115).

Violar «lo que es» es la esencia de la violencia, sea cual sea ese objeto «que es». Supongamos que estoy encolerizado. Para desahogarme, ataco algo o a alguien y así desencadeno una serie de reacciones coléricas. Eso es violencia. Pero si a mi cólera le impongo el ideal o la represión, eso también es violencia. Y esto no importa que se haga de modo brutal o refinado. Sigue siendo igualmente violencia. El hecho es que hay una violación o imposición sobre «lo que es», o sea, sobre nuestra propia realidad. Krishnamurti prolifera en ejemplos. Tengo la ambición de ser un gran poeta o lo que fuere. Y me frustro porque no llego a serlo. Esta frustración es violencia contra «lo que es», contra un hecho: el hecho de que no tengo cualidades para ser un buen poeta. Por tanto, toda acción contra una persona o cosa es violencia:

«Existe el hecho y la violación de ese hecho por otra acción. Digamos por ejemplo, que no me gustan los rusos, o los alemanes, o los americanos, e impongo mi opinión personal o mi evaluación política; eso constituye una forma de violencia. Cuando me impongo sobre usted, eso es violencia. Cuando me comparo con usted (que es más famoso, más inteligente), estoy ejerciendo violencia sobre mí mismo, ¿no es así? Soy violento. En la escuela, "B" es comparado con "A", quien es mejor en los exámenes y los pasa brillantemente. El maestro dice a "B": "tienes que ser como él"; por lo tanto, cuando compara a "B" con "A", hay violencia y destruye a "B". Vea lo que está envuelto en este hecho, que cuando impongo sobre "lo que es" aquello que "debería ser" (el ideal, lo perfecto, la imagen, etc.), hay violencia» (El vuelo del águila, p. 116).

Dada la importancia del tema, Krishnamurti lo desarrolla detenidamente. Es el núcleo del tema. Sencillamente, cualquier forma de imposición sea esta la del padre sobre el hijo, la de éste sobre aquél, la del maestro sobre el discípulo y viceversa, etc... son todas ellas formas de violencia. Tanto en el mundo interno, como en el externo, imponer algo es violencia.

Pero Krishnamurti, como es habitual, insiste en la violencia interna, porque esta es en el fondo la causa de la violencia externa, social:

«Hemos visto que siempre que me impongo a mí mismo, psicológicamente, una idea o conclusión, ello engendra violencia. (Consideremos eso por ahora). Soy cruel, verbalmente y en mis sentimientos. Me impongo sobre este hecho, diciendo: "no debo"', y me doy cuenta de que eso es una forma de violencia» (El vuelo del águila, p. 125).

O sea, que analizando cuál es la naturaleza de la violencia, qué lugar ocupa en la vida, vemos que es la violación y disciplina impuestas por uno mismo o por la sociedad sobre «lo que es», sobre la realidad. Así está servida dentro y fuera de nosotros mismos.

Pero es preciso dar un paso más y Krishnamurti lo hace. ¿De dónde emana esa violencia ejercida sobre la propia realidad o la ajena? ¿Cuáles son las raíces últimas de este terrible fenómeno humano? Krishnamurti lo tiene muy claro. Hay varias, pero una descuella por su profundidad y exige la máxima atención. Es el yo:

«La fuente de la violencia es el "yo", el ego, el yo mismo, que se expresa de tantas maneras diferentes "en la división, en tratar de llegar a ser o en ser alguien" con lo cual se divide a sí mismo como el "mí" y el "no mí", como lo inconsciente y lo consciente; el 'mí' que se identifica o no se identifica, bien sea con la familia o no con la familia, con la comunidad o no con la comunidad, etc. Es como si se tratara de una piedra tirada en un lago: las ondas se extienden y extienden, y en el centro está el "mí". Mientras sobreviva 
el "mí" en alguna forma, ya sea muy sutil o brutal, tendrá que haber violencia» (Más allá de la violencia, p. 72).

Es este un texto concentrado y expresivo de las diversas formas de proliferación del yo. Importa ver el yo como referente último de la violencia. Si percibiéramos cómo esta raíz de la violencia pudiera secarse, llevaríamos un género de vida diferente. Se pondría fin a ese interminable proceso de violencia.

Cualquier movimiento del yo, sea consciente o inconsciente, es todavía el yo en acción. Nos negamos a ver que el yo es el responsable de esa vida de violencia que llevamos. Pero esa misma negación es también obra del yo:

"Dijimos que este "yo" es una cosa viva, un movimiento. Todo el tiempo está agregando a sí mismo y quitando de sí mismo. Y este "yo", este movimiento, es la raíz de toda violencia. No sólo este "yo" como algo estático que inventa el alma, que inventa a Dios, el cielo y el castigo; es la totalidad de eso» (La conciencia fragmentada, p. 180).

Una de las manifestaciones más genuinas del yo es su deseo de realización. Quiere serlo todo, nunca está satisfecho. Trata de conseguir una cosa y, antes de realizarla, ya está proyectando otra. En esta dinámica se mide y compara con los demás en perpetua lucha e insatisfacción. Como todo lo quiere y no lo consigue, está permanentemente frustrado. Y esto es fuente de violencia. Desde otra perspectiva pues, aparece de nuevo lo mismo; que el yo es la raíz de la violencia.

En conexión con el yo, aparece otra raíz de la violencia. Es pensar y sentir en términos de opuestos: "soy esto, pero debo ser lo otro», con lo cual genero en mi mismo una tensión y violencia estructural. Soy brutal, pero, sin reconocerlo, quiero ser amable.

Mirando todo eso y viendo lo que soy, quiero ser de otra manera. Pero, mientras haya dualidad en mí, habrá tensión y violencia entre lo que soy y lo que quiero ser.

Por tanto no es cuestión de buenos propósitos ni de fuerza de voluntad sobre aquellas cosas que en nosotros generan la violencia:

"La voluntad es en el fondo violencia". Examinamos lo que es la voluntad: "deseo hacer eso" "no aceptaré eso" "haré eso" "yo resisto", "yo exijo", "yo deseo", las cuales son formas de resistencia. Cuando usted dice, "me propongo eso" "ello es una forma de resistencia", y la resistencia es violencia» (Más allá de la violencia, p. 76).

Si nos damos cuenta de que los problemas que tenemos existen en términos de opuestos, esos problemas se desvanecerán. Hay una realidad: soy cruel y un esfuerzo en querer no serlo. Esa es la contradicción que genera violencia interna; hay un conflicto entre «lo que es» y «lo que debería ser». El problema cesará cuando abordamos con discernimiento «lo que es», lo que somos.

Esta idea de querer ser lo que no somos nos lleva a descubrir una nueva raíz de la violencia: la búsqueda de seguridad. Nos proyectamos de modo constante en ideales que quisiéramos alcanzar para sentirnos mejor, más seguros. Sólo con lo que tenemos, vacilamos. Buscamos una seguridad psicológica por medio del poder, posición, títulos, riqueza, etc.; y eso nos conduce a una escalada que genera violencia. Al buscar ansiosamente eso y no encontrarlo, nos enfrentamos con aquello que no nos dio las expectativas que pusimos. Pero esa seguridad psicológica no existe:

«La principal causa de violencia, a mi entender, es que cada uno de nosotros, internamente, psicológicamente, busca la seguridad. En cada uno de nosotros el impulso por la seguridad psicológica "esa sensación interna de estar a salvo" se proyecta en la exigencia de seguridad externa. Internamente, cada uno de nosotros quiere estar seguro, tener certidumbre acerca de todo. Por eso tenemos todas estas leyes matrimoniales, a fin de que podamos poseer a una mujer, o a un hombre y, de ese modo, 
poder sentirnos seguros en nuestra relación. Si esa relación es atacada nos volvemos violentos; tal violencia tiene origen en la exigencia psicológica, interna, de sentirnos seguros en nuestras relaciones con todo. Pero en ninguna relación hay tal cosa como la certidumbre, la seguridad. Internamente, psicológicamente, nos gustaría estar seguros, pero la seguridad permanente no existe» (El libro de la vida, 27 de junio).

Y finalmente, justo por esta lucha interna que el hombre mantiene consigo mismo, emerge otra raíz de la violencia que es el temor. En cuanto hay temor, tiene que haber violencia:

«Abordemos ahora este problema de una manera diferente. En tanto haya temor, tiene que haber violencia, agresión, odio e ira. Casi todos los seres humanos están atemorizados, no sólo con respecto a lo externo sino también internamente, aunque lo externo y lo interno no están separados, son realmente un solo movimiento. De modo que si entendemos lo interno "su propósito, su naturaleza y toda la estructura del temor», entonces tal vez seremos capaces de dar origen a una sociedad diferente, a una cultura diferente, porque la sociedad actual está corrupta y su moralidad es inmoral» (Conversaciones con estudiantes, p. 145).

Tal es el panorama que dibuja Krishnamurti respecto a la naturaleza y las raíces de la violencia. Se plantea ahora el reto de su trascendencia o superación.

\title{
4. Posibilidad de liberación de la Violencia
}

El problema de la violencia es tan grave que nos afecta interna y externamente. Es causa de nuestra desgracia en el mundo. Y sus implicaciones llegan a los diversos ámbitos de la vida. Estamos envueltos en ella por todas partes. Y es preciso plantearse con seriedad si podemos "y hasta dónde" erradicarla:

\begin{abstract}
«Nos enfrentamos, pues, a este problema: el problema de la violencia. Y uno tiene que preguntarse si es del todo posible para un ser humano, no sólo en su relación personal sino en su relación con la sociedad, estar completamente libre de esta violencia. No es una pregunta retórica ni un interrogante intelectual, sino un problema real que afronta cada uno de nosotros tanto psicológicamente, en lo interno (bajo la piel, por así decir) sino también exteriormente, en el hogar y en la oficina. En toda forma de actividad existe este espíritu agresivo, el cual engendra odio y animosidad. También estuvimos preguntándonos si es del todo posible, no sólo en el nivel consciente sino también en los niveles mentales más profundos, erradicar por completo esta violencia, de manera que podamos vivir en paz unos con otros e ir más allá de las divisiones nacionales, de la separación religiosa con sus dogmas, creencias, teorías e ideología» (Conversaciones con estudiantes, pp. 141-142).
\end{abstract}

Krishnamurti se pregunta, en este punto, cuáles son las implicaciones de violencia. Y si la mente humana puede, de hecho, resolver tanto los problemas sociales como internos que conlleva la violencia. Y naturalmente sin que esa posible solución genere a su vez violencia. Porque entonces sería una espiral sin fin, la pescadilla que se muerde la cola.

Se trata pues de saber si el mundo exterior, la estructura social, la injusticia, la brutalidad, las guerras... pueden ser cambiadas así como la batalla interna que prosigue en nosotros de modo continuo e interminable. ¿Puede todo esto cambiar sin conflicto, sin oposición? ¿Cómo producir este cambio tanto en lo externo como en lo interno? ¿Podemos ir a la raíz misma de la violencia y librarnos de ella? Porque de lo contrario, viviremos en continua lucha unos con otros. 
A este planteamiento, Krishnamurti añade ahora un primer matiz ¿Podemos poner fin a la violencia cuando todo a nuestro alrededor está impregnado de ella? ¿Tenemos que hallar una islita en medio del océano? ¿Cómo sobrevivir en un lugar en que todos están combatiendo unos con otros? Krishnamurti ve la posibilidad de no ser violento en un mundo que lo es:

«Así pues, quienes podemos comunicarnos consideremos juntos si es posible poner fin a toda forma de violencia en nosotros mismos y seguir viviendo en este mundo brutal. Por mi parte, creo que es posible. No quiero albergar ni una pizca de odio, celos, inquietud o temor. Deseo vivir completamente en paz, lo cual no significa que quiera morir. Quiero vivir en esta tierra maravillosa, tan plena, tan rica, tan hermosa. Quiero contemplar los árboles, las flores, los ríos, los prados, las mujeres, los chicos y chicas y, al mismo tiempo, vivir por completo en paz conmigo mismo y con el mundo ¿Qué puedo hacer?» (Limpia tu mente, pp. 61-62).

Krishnamurti señala un segundo matiz en este planteamiento: para poder vivir sin violencia en un mundo rebosante de ella, es preciso que uno, interiormente, esté libre de ella:

«Ese es realmente un problema muy difícil, ¿no es así? Mi vecino es violento: ¿cómo bregaré con él? ¿volver la otra mejilla? Él está muy contento. ¿Qué debo hacer? ¿Se haría usted esa pregunta si fuera realmente no-violento, si no hubiera violencia en usted? Le ruego que preste atención a esta pregunta. Si en su corazón, en su mente, no hay violencia en absoluto, ningún odio, ninguna amargura, ningún sentido de realización, ningún deseo de ser libre, ninguna violencia, ¿se haría usted esa pregunta de cómo se enfrentaría a su vecino que es violento? ¿O sabría usted entonces qué hacer con su vecino? Otros podrían calificar de violento lo que usted hace, pero puede que usted no sea violento; tan pronto su vecino actúe violentamente, usted sabrá cómo afrontar la situación. Pero una tercera persona que esté observando podría decir:'Usted también es violento'. Sin embargo, usted sabe que no lo es. Por lo tanto, lo importante es que para sí mismo está completamente sin violencia y no importa cómo otro lo llame» (Más allá de la violencia, pp. 80-81).

En este texto Krishnamurti introduce un elemento clarificador para no llamarse a engaño. Una conducta puede aparentar ser violenta y no serlo en realidad. ¿Quién decide entonces? Uno mismo por dentro, sabiendo qué es o que quiere, cómo y de qué manera lo realiza. En muchos ámbitos de la existencia, vg.: la educación, el trabajo, etc., uno tiene que tomar determinaciones firmes o realizarlas con firmeza. Puede dar apariencia de violento sin serlo.

Pero Krishnamurti sigue despejando el camino de la liberación de la violencia. Y añade ahora otro aspecto. ¿Queremos realmente estar libres de toda violencia?:

"¿Nosotros vemos aquí la importancia de estar totalmente libres de cualquier forma de violencia? ¿O nos gustaría conservar ciertas partes de ella? ¿Es posible estar completamente libres de toda violencia?, eso significa estar libres de toda irritación, de toda ira, de cualquier tipo de ansiedad y de cualquier forma de resistencia» (La conciencia fragmentada, p. 166).

Por último, Krishnamurti encara la violencia en su liberación, desde la violencia misma, sin mirar a su contrario. Aquí refleja, una vez más, una de las constantes de sus enseñanzas: es la negación de la dialéctica de contrarios. Una cosa tiene que esclarecerse en si misma sin relacionarla con su contraria. El opuesto no se sale del ámbito que plantea su contrario. Por consiguiente, es preciso encarar la violencia sin hacer referencia a su contrario, la no-violencia: 
«¿Conoce usted la violencia porque conoce la no-violencia? ¿Sabría lo que es la violencia sin el opuesto? Porque conoce estados de no-violencia, ¿reconoce, por lo tanto, la violencia? ¿Cómo conoce la violencia? Porque uno es agresivo, competidor, y ve los efectos de todo eso, que es violencia, uno construye un estado de no-violencia. ¿Si no hubiera el opuesto, sabría lo que es la violencia?» (El vuelo del águila, p. 113).

Este punto es el que dará lugar a la controversia de Krishnamurti con los seguidores de Ghandi. Sabido es cómo éstos eran partidarios de la no-violencia. Pero Krishnamurti les objetará que ningún valor o cualidad verdaderos son negación de otro. El valor auténtico tiene su consistencia en si mismo, sin tener que ver con el contrario. Aplicado al caso de la no-violencia, quiere decir que quien milita en ésta no se ha desembarazado del ámbito de la violencia. Dicho en pocas palabras, se puede tratar de ser no violento siendo violento en el fondo del alma. Un hombre pacífico no necesita trabajar en la noviolencia. Cuando se aspira a ser no violento es porque en el fondo se es violento.

Hecho el planteamiento, Krishnamurti despeja el camino hacia la liberación de la violencia señalando un punto esencial. Es preciso comenzar por la violencia interna. Él tiene muy claro que la raíz está en nosotros, no fuera. La sociedad es la proyección de lo que nosotros somos. Bien es cierto que la sociedad es violenta y que luego influye y determina a los individuos. Se inicia así una espiral a la que hay que poner fin. Y esto se hace yendo a la raíz. Y ésta está fundamentalmente en el individuo. En este sentido conviene recalcar, antes de entrar en pormenores que, en general, un problema no puede ser resuelto en su propio plano o nivel, sino desde otro diferente y más profundo. La violencia aparece en primer plano o nivel en la sociedad. Ahí muestra extensión, brutalidad y consecuencias. Pero hay que investigar en otro nivel las causas de ese fenómeno.

Por tanto, el nivel adecuado de planteamiento de la violencia es el propio individuo en su interior y para esto no hace falta hacer grandes cosas, sino estar atentos a nuestra vida cotidiana en la que entran en juego las pasiones, deseos e impulsos que terminan en la violencia social, en la guerra.

Siendo la violencia interna de la misma naturaleza que la externa, se trata de abordarla en su origen, no de manera fragmentada, sino completa, holística. Así sería el verdadero abordaje de la violencia:

«¿Hay, acaso, diferencia entre la ira individual con su acción violenta por parte del individuo, y el odio organizado de una sociedad que engendra, y forma un ejército para destruir a otra sociedad? ¿Dónde, en qué nivel, y qué fragmento de la violencia están ustedes discutiendo? ¿ O quieren discutir si el hombre puede estar libre de la violencia en su totalidad, no de un fragmento en particular al que llamamos violencia?...

Sabemos qué es la violencia cuando no se expresa en palabras, en frases, en actos. Como ser humano en quien el animal es todavía muy fuerte, a pesar de los siglos de la así llamada civilización, ¿por dónde he de comenzar? ¿Comenzaré por la periferia, que es la sociedad, o por el centro, que soy yo mismo?»(El libro de la vida, 23 de junio).

Por consiguiente depende de nosotros, de cada uno, la eliminación de la violencia y no de los hombres de Estado, de los dirigentes:

«Así es que repito: depende de vosotros y no de los dirigentes, no de los llamados hombres de Estado, ni de los demás. Depende de vosotros y de mí, pero no parece que nos demos cuenta de ello. Si por una vez sintiéramos realmente la responsabilidad de nuestros propios actos, jcuán pronto pondríamos fin a todas estas guerras, a todo este espantoso sufrimiento! Pero, como veis, no nos importa mucho» (La libertad primera y última, p. 193). 
La guerra y las demás manifestaciones externas de la violencia son pues una proyección de nuestra guerra interna.

Y concluye este punto Krishnamurti con otra precisión. La violencia está dentro, pero, además, la tarea de erradicarla debe comenzar ahora en el presente y no perder el norte dejando el remedio para el futuro o echándole la culpa al pasado. Es decir, hay que poner manos a la obra ahora, evitando la codicia, la mala voluntad, etc. que son las causas que generan la violencia y la guerra:

«El presente es lo eterno; ni el pasado ni el futuro pueden revelarlo. Lo intemporal se realiza sólo a través del presente. Si usted desea de verdad salvar a su hijo y, por ende, a la humanidad, de otra guerra, entonces debe pagar el precio por ello: no ser codicioso, no tener mala voluntad y no ser mundano; porque la apetencia sensual, la mala voluntad y la ignorancia producen conflicto, confusión y antagonismo; engendran el nacionalismo, la arrogancia, y promueven la tiranía de la máquina. Si usted está dispuesto a liberarse de las apetencias sensuales, la mala voluntad y la ignorancia, sólo así salvará a su hijo de otra guerra. Para traer felicidad al mundo, para poner fin a estos asesinatos en masa, tiene que haber una completa revolución interna del pensar y sentir que dé origen a una nueva moralidad, a una moralidad no basada en los sentidos sino en la libertad respecto del sensualismo, del espíritu mundano y del anhelo de inmortalidad personal» (El espejo de la relación, Obras Completas, tomo III, p. 315).

Despejado ya el campo de la interioridad humana como lugar de la violencia, Krishnamurti atiende ahora otros mecanismos que impiden su liberación: son la huída, la represión, la negación. ¿Podemos considerar la violencia, el odio, etc. sin reprimirlos ni justificarlos, lo cual significa que no les oponemos resistencia?:

«¿Puede usted considerar la ira sin ninguna explicación o justificación, sin decir "debo proteger mis bienes" o "tenía razón al enfadarme" o "qué estúpido he sido al enfadarme"? ¿Puede considerar la ira como tal? ¿Puede examinarla con una objetividad total, es decir, ni defenderla ni condenarla? ¿Puede hacer tal cosa?

¿Puedo mirarle igual tanto si le soy hostil como si pienso que es usted una persona maravillosa? Sólo puedo verle de verdad cuando le miro con cierto cuidado, prescindiendo de tales sentimientos. Pues bien, ¿es posible examinar la ira de la misma manera, lo cual significa que soy vulnerable al problema, que no le ofrezco resistencia, que observo este fenómeno extraordinario sin reaccionar a él en absoluto?» (Limpia tu mente, pp. 65-66).

Contra la violencia no vale resistencia, ni combate, ni imposición porque estas cosas son voluntad y ésta es violencia. De modo que así opondríamos violencia a violencia.

Cuando reprimimos la violencia con fuerza de voluntad no sólo no eliminamos aquélla, sino que la fortificamos:

«Usted se convierte en aquello mismo contra lo que combate, no hay duda [...]. Si yo estoy furioso y usted me enfrenta con furia, ¿cuál es el resultado? Más furia. Usted se ha convertido en aquello que soy yo. Si soy malo y usted me combate con el mal, significa que también usted se vuelve malo, por justo que pueda sentirse. Si soy brutal y usted usa métodos brutales para vencerme, entonces se ha vuelto tan brutal como yo. Y esto es lo que hemos hecho durante miles de años. Por cierto, hay una manera de abordar esto, distinta a la de enfrentarse con odio al odio. Si uso métodos violentos para calmar la furia que hay en mí, entonces estoy usando malos medios, para un buen fin y, debido a eso, el buen fin deja de ser tal. De este modo no hay comprensión, no trasciende la furia. La furia debe ser estudiada con tolerancia y comprendida; no puede ser vencida por medios violentos. Ella puede ser el resultado de muchas causas y, sin comprenderlas, no hay manera de escapar de la furia» (El libro de la vida, 30 de junio). 
Por tanto, somos nosotros mismos los que creamos al enemigo. Y convertirnos nosotros mismos en el enemigo, no origina el fin de la violencia. Es preciso comprender la causa de la hostilidad y dejar de alimentarla con nuestros pensamientos, sentimientos y acciones.

Podemos desembarazarnos de la ira y la violencia por la represión, por la fuerza de voluntad. Pero si la mente y el corazón no cambian, seguiremos siendo violentos.

Krishnamurti apunta a una percepción alerta como instrumento con el que abordar la violencia, pero está muy lejos de entender aquélla según el modo habitual de nuestro conocer. El conocimiento tampoco resuelve el problema de la violencia. Krishnamurti lo plantea en sus justos términos. Aquí hay un hecho: somos crueles, violentos. Eso es un problema y ningún tipo de explicación podrá resolverlo.

Y esto ¿por qué? Porque el conocimiento no es el medio de trasformación del hombre:

«La energía que se ha dedicado a la acumulación de conocimientos, no ha cambiado al hombre, no ha puesto fin a la violencia. La energía que se ha invertido en millares de explicaciones de por qué el hombre es tan agresivo, tan brutal e insensible, no ha puesto fin a su crueldad. La energía que se ha gastado en analizar las causas de su insana destrucción, de su placer en la violencia, de su sadismo, de su pendenciera actividad, en modo alguno ha hecho que el hombre sea más benévolo y considerado. A pesar de todas las palabras y los libros, de las amenazas y los castigos, el hombre continúa con su violencia» (Diario II, p. 77).

Y de manera especial llama Krishnamurti la atención a esa especial forma de conocimiento que se ha utilizado para abordar la violencia y los problemas existenciales humanos: el análisis:

"¿Pero qué podemos hacer quienes deseamos librarnos de la violencia? No creo que se vaya a conseguir nada por medio del análisis, ya sea realizado por nosotros mismos o por un profesional. Podríamos ser capaces de modificarnos ligeramente, vivir algo más tranquilos con un poco más de afecto, pero esto por sí solo no nos proporcionará una percepción total» (Limpia tu mente, p. 69).

Pero si el conocimiento no libera de la violencia, tampoco los ideales. Éstos tiran de nosotros queriéndonos arrastrar hacia lo alto y lo sublime; pero dejan intacta nuestra verdadera realidad en la que estamos inmersos:

«Algunos de nosotros, a fin de desembarazarnos de la violencia, hemos utilizado un concepto, un ideal, llamado no violencia, y creemos que al poseer un ideal de lo contrario de la violencia, la no violencia, podemos librarnos del hecho real... pero no podemos. Tenemos innumerables ideales, todos los libros sagrados están llenos de ellos, pero seguimos siendo violentos. Así pues, ¿por qué no ocuparnos de la misma violencia y olvidar el término por completo?

Si desea usted comprender lo real, debe prestarle toda su atención, toda su energía. Esa atención y energía se distorsionan cuando usted crea un mundo ficticio, ideal. ¿Es posible eliminar el ideal? El hombre realmente serio, con el impulso de averiguar qué es la verdad, qué es el amor, no tiene ningún concepto en absoluto. Vive tan sólo en lo que es» (Limpia tu mente, pp. 69-70).

Es también una constante en el pensamiento de Krishnamurti esta denigración de los ideales. Es algo que a nosotros los occidentales nos deja estupefactos. ¿Cómo no tener ideales que nos impulsen a una realidad más alta, a mejorar? La respuesta de Krishnamurti es idéntica: ¿cómo se puede mejorar camuflando la realidad; huyendo de lo que somos?. 
Como puede verse, Krishnamurti es especialmente sensible a ese ideal de la no-violencia que le rodeó en la India y que, como se señaló antes, le enfrentó a los seguidores de Gandhi. Por eso insiste en ello en respuesta a una pregunta de un oyente:

«¿No es importante saber que sois así, y no pretender idealmente ser no-violento, y otras tonterías? El hecho real es que sois violentos; y creo que el problema está en que no os dais cuenta de que lo sois, porque siempre estáis pretendiendo ser no-violentos. Se os ha educado, criado, enseñado en el ideal de la no-violencia; pero el ideal es cosa falsa, no existe en absoluto. Lo que existe es lo que sois, que es el ser violentos, y la brecha entre el ideal y el hecho crea esta hipócrita existencia dual que es una de nuestras desgracias en este país. Todos vosotros sois personas así idealistas, siempre estáis hablando sobre la no violencia y masacrando a vuestros vecinos (risas). Señores, no riáis, no es cosa divertida. Son hechos. ¿Queréis decir que toleraríais la pobreza, la degradación, los horrores que existen en cada ciudad y aldea de la India, si fuerais realmente misericordiosos? No sois misericordiosos y compasivos de hecho, sólo lo sois en teoría, y es por eso que vivís vidas duales» (La crisis del hombre, pp. 152-153).

El hecho es mucho más importante que lo que debería ser. En vez de perseguir el ideal de la no-violencia que no existe es mejor reconocer el hecho de ser violentos y poner ahí la atención. Tal es el inicio del camino para acabar con la violencia.

Todavía Krishnamurti añade un matiz a este problema: cuanto mayor es el ideal, mayor será el conflicto y el antagonismo. Prosigue Krishnamurti la reflexión que abre camino a la eliminación de la violencia. Han sido descartados la represión, la huida, el conocimiento y los ideales. Ahora aborda otros aspectos del signo positivo. He aquí el primero de ellos: para eliminar la violencia hace falta pasión, sumo interés:

«Ahora bien, si usted quiere detener la violencia, quiere detener las guerras, ¿cuánta vitalidad, cuánto esfuerzo pone en el empeño? ¿No es importante para usted que maten a sus hijos, que vayan al ejército, donde los tiranizan y matan? ¿No le preocupa? Dios mío, si eso no le interesa, ¿qué será lo que despierta su interés? ¿Guardar su dinero? ¿Pasarlo bien? ¿Tomar drogas? ¿No ve que esa violencia en usted mismo está destruyendo a sus hijos? ¿O acaso lo ve tan sólo como una abstracción?» (Limpia tu mente, p. 67).

No es suficiente haber tenido una mera insinuación del problema. Se trata de descubrir si es posible vivir sin violencia y eso es algo apasionado; no se trata de meras fantasías ideológicas. Hace falta querer realmente descubrir: ¿es posible para mi vivir completamente sin violencia?.

Para poner fin a la violencia no vale asentir o estar de acuerdo. Porque todo seguirá lo mismo. El estar de acuerdo es algo puramente verbal y carente de significado. Es preciso ver el peligro de la violencia, percibir la responsabilidad y, sobre todo, la urgencia de ponerle fin de manera inmediata.

Junto a esta pasión y urgencia, Krishnamurti aduce otro factor: un verdadero conocimiento de sí mismo:

«Abordemos ahora este problema de otro modo. Una de nuestras dificultades principales, me parece, es que aunque tengamos abundancia de energía, aparentemente nos falta el impulso, la vitalidad y el entusiasmo para producir este cambio dentro de nosotros. Después de todo, conocernos a nosotros mismos "no de acuerdo con algún especialista" es lo más importante, es la base de toda acción. Y si no nos conocemos a nosotros mismos, si no nos estudiamos, si no aprendemos al respecto y penetramos en ese espíritu meditativo dentro de nosotros, entonces faltan los cimientos, toda acción se vuelve fragmentaria, contradictoria; y desde este estado de contradicción surge el conflicto y este conflicto es el que nos agobia a cada uno de nosotros. Todo lo que hacemos, todo lo que pensamos, todo lo que tocamos engendra conflicto y lucha, lo cual 
en múltiples formas derrocha energía que es absolutamente vital para esta revolución psicológica interna. Esto implica que, internamente, debemos estar por completo libres del conflicto» (Conversaciones con estudiantes, pp. 142-143).

Este conocimiento de sí mismo es el campo privilegiado de acción. En él se ven los problemas humanos reflejados como en un espejo. Y así se convierte en el pequeño laboratorio en el que cada hombre debe trabajar para sí y para el resto. De esta forma lo vivieron tanto los griegos como los hindúes: "conócete a ti mismo». El problema de la violencia debe ser observado en ese espejo del conocimiento de sí.

Y para ello, para el recto conocimiento de sí, no debemos estar manejados, manipulados ni guiados por otros. Si somos ignorantes de nosotros mismos "cosa harto frecuente" se nos conduce, se nos maneja y se nos obliga a aceptar. Es preciso pues estar alerta de cada movimiento del yo para que surja el recto conocimiento de sí mismo. Por tanto, es preciso trabajar en este sentido y no dejar pasivamente la responsabilidad a otros.

Ese conocimiento de sí mismo conduce claramente al núcleo del problema: que es la transformación que debe llevar a cabo en sí mismo el individuo. Tal es el reto último que plantea la eliminación de la violencia. Ante la panorámica de explotación, crueldad y violencia en que se debate nuestro mundo, nuestra sociedad, caben dos soluciones, dice Krishnamurti: la de tolerar esas cosas haciendo alguna crítica ineficaz o queriendo realmente una verdadera transformación, un cambio. La primera es una labor de remiendos, de reformas y la segunda una reorientación completa del pensamiento y la acción. Así describe la primera.

La segunda, la transformación radical, consiste en encarar nuestra estructura psicológica y tratar de cambiarla: es decir, vérnoslas con nuestro egocentrismo, afán de engrandecimiento, etc. que son las raíces de la violencia:

«Esta mañana quiero mostrar, pues, que en tanto el pensamiento y, por ende, la acción, se basen en esta idea del engrandecimiento propio, del crecimiento propio, o en la continuamente limitada conciencia egocéntrica, tiene que haber problemas que emanan de esta conciencia limitada. Es decir, si ustedes hacen cualquier clase de cambios o reformas sociales, mientras el sistema de pensamiento se base en el afán posesivo, en la seguridad, en los derechos de propiedad y demás, tendrá que haber problemas que sólo podrán ser abordados de manera sintomática, no radical. Es como acudir a un médico que trata sólo con los síntomas y no con la causa de la enfermedad» (Obras Completas, tomo I, El arte de escuchar, p. 16).

Por tanto, desear sólo la reforma, o sea, producir algunos cambios que pueden paliar las manifestaciones de la violencia, es sólo postergar o alejar por el momento la cuestión fundamental. Ésta es el cambio completo del individuo. Es necesario un mundo nuevo, una cultura nueva. Y ésta no puede basarse en la violencia. La nueva cultura depende de nosotros porque las viejas generaciones han construido una cultura basada en la violencia, en la agresividad y eso ha generado este mundo cruel:

«Vemos actualmente cómo el mundo del odio recoge su cosecha. Este mundo del odio ha sido creado por nuestros padres y sus antecesores, así como por nosotros. De este modo, la ignorancia se extiende indefinidamente hacia el pasado. No ha surgido a la existencia por sí misma. Es el resultado de la ignorancia humana, es un proceso histórico, ¿verdad? Nosotros como individuos hemos cooperado con nuestros antepasados, quienes, con sus antecesores, pusieron en marcha este proceso de odio, miedo, codicia y demás. Ahora bien, como individuos, nosotros pertenecemos a este mundo del odio, en tanto nos entreguemos, individualmente, a él.

El mundo es, por consiguiente, una extensión de nosotros mismos. Si usted, como individuo, desea destruir el odio, entonces, como individuo, debe dejar de odiar. Para 
destruir el odio, usted mismo debe disociarse del odio en todas sus formas, groseras y sutiles; en tanto esté preso en ellas, forma parte de ese mundo de ignorancia y miedo. Entonces el mundo es una extensión de usted mismo, es usted mismo duplicado y multiplicado» (El libro de la vida, 29 de junio).

Por tanto, para que en el mundo haya paz y termine la violencia, debe darse primero una revolución interna en el individuo:

«Para procurar la paz en el mundo, para detener todas las guerras, tiene que haber una revolución en el individuo, en vosotros y en mí. La revolución económica carece de sentido sin esta revolución interna, pues el hambre es el resultado de un desajuste en las condiciones económicas, producido por nuestros estados psicológicos: codicia envidia, mala voluntad y espíritu de posesión. Para poner fin al dolor, al hambre y a la guerra es preciso que haya una revolución psicológica, y pocos de nosotros estamos dispuestos a enfrentarnos con eso» (La libertad primera y última, p. 194).

Y, por ultimo, ese cambio o transformación radical no puede hacerse paulatinamente, mediante una evolución retardada en el tiempo. Más bien es instantáneo: cuando la casa está ardiendo no nos ponemos a hacer planes y a reflexionar, actuamos inmediatamente para apagar el fuego:

«Pero ustedes responderán que tomará muchísimo tiempo lograr que cada uno de nosotros cambie y pueda así convencer a otros acerca de este punto de vista; que la sociedad no está preparada para recibir esta idea; que los políticos no se interesan en ella; que los líderes son incapaces de concebir un gobierno universal o un Estado sin soberanías separadas. Ustedes podrían decir que éste es un proceso evolutivo que producirá de manera gradual ese cambio tan necesario...Esta teoría evolucionista de una paz gradual, ¿'es verdadera, o la hemos inventado para racionalizar nuestra pereza y nuestro egocéntrico pensamiento-sentimiento? ¿Acaso no es incompleta y, por lo tanto, falsa?» (Obras completas, tomo III, o.c., p. 314).

\section{LA ERRADICACIÓN DE LA VIOLENCIA: LA ATENTA OBSERVACIÓN}

Después de analizar las actitudes que impiden afrontar debidamente la violencia, Krishnamurti da un paso más. Un paso importante en sintonía con sus enseñanzas. Se trata de ir a la violencia misma, sin ánimo de hacer nada con ella: condenarla, justificarla o trasformarla. Sencillamente es verla en sí misma con todo detenimiento. Verla tal como es, mirarla, observarla intensamente se trata de ver lo real y no nuestras proyecciones. Resulta demasiado duro ver lo que somos. Y ello nos inquieta, causa dolor, preocupación, ansiedad... Es algo terrible de lo que quisiéramos desembarazarnos. Por tanto la primera tentación es huir: huir hacia ideales u otros medios peores como proyectar esa violencia en los demás. La mente tiene que ver con claridad que no hay escape al hecho de nuestra violencia:

«Tengo que darme cuenta de que la mente no puede ser distraída del hecho de la violencia, ni buscando la causa, ni en la explicación de la causa, ni nombrando el hecho de que soy violento, ni justificándola, ni condenándola, o tratando de deshacerme de ella. Todas esas son maneras de distraerse del hecho de la violencia. La mente tiene que ver con absoluta claridad que no existe escape que nos libre de ella; ni puede existir el ejercicio de la voluntad que dice: "La conquistaré" la voluntad es la esencia misma de la violencia» (Más allá de la violencia, p. 75). 
Uno ve los estragos que hace la violencia: guerras en lo exterior, conflictos en la relación, luchas internas en uno mismo. Y entonces nos planteamos que tiene que haber otra manera diferente de vivir. O aceptamos este modo de vida de violencia o la inteligencia tiene que hallar otro camino.

Pero lo que importa en este momento es que volquemos nuestra visión e interés en el hecho mismo de ser violentos. En ser conscientes de él. No es necesario, por ahora, tratar de cambiar, de convertirse o de hacerse mansos, es preciso detenerse y no salir corriendo porque nos escuece demasiado. Y hacemos enseguida propósitos que vuelven pronto a ser conculcados porque no se ha detenido lo suficiente en ver el problema. Y ante ese ansia de cambio rápido, se trata de aguantar y estar viendo pasivamente la violencia:

«Cuando estáis esperando algo, positiva o negativamente, estáis proyectando vuestro propio deseo; conseguiréis vuestro deseo, pero eso no será más que una nueva sustitución, y así, la batalla continúa de nuevo. Este deseo de lograr o de eludir sigue estando dentro del campo de la oposición, ¿no es cierto? Ved lo falso como falso, y entonces la verdad será. No tendréis que buscarla. Lo que busquéis, lo encontraréis, pero no será la verdad. Es como un hombre que sospecha y que encuentra lo que sospechaba, lo cual es relativamente fácil y estúpido. Sólo daos cuenta pasivamente de todo este proceso del pensamiento, y también del deseo de libraros de él» (Comentarios sobre el vivir, $1^{\text {a }}$ serie, p. 247).

Se trata de ver la violencia de modo exhaustivo en sus modalidades, matices, afecciones. Viéndola como si observáramos un animal nuevo y extraño.

Por tanto esta vez tiene que ser algo con sentido e intencionalidad en sí mismo, carente de motivos; así llegará a la realidad. El ver carece de motivaciones, simplemente ve. Y aquí lo que se ve es simplemente la violencia que hay en el mundo y que forma parte de mi. ¿Lo veo? ¿Puedo observar la violencia sin ninguna distorsión? Porque ésta impide la observación.

Y una extorsión importante es ver la violencia con sus acumulaciones ideológicas y temporales; la visión ha de estar limpia de todo eso.

Esta eliminación del pasado conlleva simultáneamente también la desaparición de las imágenes que distorsionan la realidad. Es este un punto muy específico de Krishnamurti.

«Puede observar la violencia en forma nueva, fresca, únicamente cuando se da cuenta de que está identificando lo que ve con las imágenes de lo que ya conoce, y de que, por lo tanto, no está observándola de nuevo. Surge, pues, la pregunta: ¿cómo se forman esas imágenes, cuál es el mecanismo que forma las imágenes? Mi esposa me dice: "Tú eres un tonto". No me gusta eso, y ello deja una huella en mi mente. Dice alguna otra cosa, y eso deja también una cicatriz en mi mente. Estas cicatrices son las imágenes de la memoria. Pero si en el mismo momento en que ella me dice, "Tú eres un tonto", estoy atento y me doy cuenta, entonces no queda huella alguna "puede que ella esté en lo correcto".

De manera que la inatención genera imágenes; la atención libera la mente de la imagen. Esto es muy sencillo. De la misma manera, si cuando tengo ira estoy completamente atento, entonces no existe la inatención que permite que el pasado surja e interfiera con la percepción real de la ira en ese momento» (Más allá de la violencia pp. 75-76).

El ver u observar sin imágenes conduce a experimentar la violencia sin nombrarla. La violencia es una cualidad muy inquietante y pocos la experimentan inmediatamente sin nombrarla.

Y ¿qué ocurre cuando se da esta visión directa e inmediata sobre la violencia? Que la inteligencia actúa. No mi conocimiento condicionado, sino la visión real de mi realidad. 
Lo que verdaderamente ocurre es que, de esa visión nace la auténtica acción. Así lo expresa Krishnamurti hablando del odio:

«Abórdelo, como he dicho, con todo su ser, como aborda el amor. Cuando ama a alguien intensamente, lo hace con toda su naturaleza, con todo su ser; en eso no hay conflicto, usted no pregunta cómo salirse de ello. Haga lo mismo con el odio, con los placeres efímeros: todas estas cosas deben ser abordadas de manera total. Entonces no se librará de ellas, sino que las comprenderá y descubrirá su plena significación, su verdadero valor, y la acción surge, entonces, desde ese descubrimiento. Así que, por favor, no considere estas cosas como algo de lo cual tiene que librarse, algo a ser conquistado. Ese enfoque impide la acción completa y, en consecuencia, hay conflicto. Y usted no puede superarlo, vencerlo; eso sólo crea más dualidad, más opuestos. Pero si aborda estas cosas tanto con el corazón como con la mente, entonces se disuelven por sí mismas, entonces puede comprenderlas plenamente. Ha nacido un elemento nuevo» (Obras completas, tomo I, p. 66).

Dada la importancia del ver, todavía Krishnamurti hace explícita una observación que late en lo dicho anteriormente. Hay dos acciones de ver. Una el simple ver. Y otra el yo que ve; o sea, el «ver» y el «yo veo». ¿Es posible ver sin el yo? El proceso de ver es diferente del proceso de moverse en determinada dirección hacia algo:

«El proceso de ver es por entero diferente. No es un proceso. No quiero usar esa palabra. El ver es ver ahora, no es un proceso de ver. Ver es actuar. Pues bien; ¿la mente ve este mapa total de la violencia y su raíz? ¿Y qué es aquello que lo ve? Si es el "yo" entonces, como éste teme vivir de un modo diferente, dice: "Debo protegerme, debo resistir esto, tengo miedo". Por lo tanto, el "yo" rehúsa ver el mapa. Pero el ver no es el "yo".

¿Nos damos cuenta de que la mente que observa todo el mapa es por completo diferente del "yo" que lo ve y teme desprenderse de él? Existen dos observaciones distintas: el "yo veo", y el "ver". El "yo" debe, inevitablemente, ver con temor y, por lo tanto, resiste y dice: “¿Cómo viviré?” ¿qué haré?, ¿debo renunciar a esto?, ¿debo retenerlo?, etc. Nosotros dijimos: Todo movimiento del "yo" es violencia. Pero hay un simple ver el mapa, que es por completo diferente» (La conciencia fragmentada, pp. 181-182).

Hay pues dos acciones de ver: el simple ver, o sea, ver el mapa de la violencia sin dirección y sin propósito y el "yo veo" con su propio impulso, intereses y resistencias; el yo ve y teme hacer esto o aquello. El simple ver es un ver que sólo observa, sin objetivos, sin propósitos determinados. Este ver sin el yo es enormemente difícil. Y ¿qué es lo que se ve sin el yo? Que toda la estructura del yo es violencia.

Cuando es el yo quien ve, hay conflicto. Veo el campo entero de mi violencia y quiero eliminarlo, cambiarlo o desecharlo. Entro en lucha conmigo mismo. Hay división porque me veo distinto de mi violencia y la combato. Hemos separado el yo de la violencia; por tanto, hay división, hay conflicto. En cambio la verdadera observación me muestra que el yo es también violencia, yo soy violencia. Por consiguiente no hay división o conflicto entre dos estados que se repelen. Hay uno sólo: el estado de violencia. Por tanto cesa la lucha y dejo de «actuar» sobre la violencia. Cesa el conflicto y no convierto la violencia en una abstracción o idea; sino que encaro ese hecho: soy violencia. Eliminando el yo o sujeto, cesa el análisis:

«Por favor, no estoy tratando de analizarlos, lo cual es algo por completo diferente y no tiene nada que ver con lo que estamos discutiendo. ¡Penetremos, pues, en ello paso a paso! Cuando el observador descubre por sí mismo que es lo observado, que es la violencia y que ésta no es algo separado de él mismo que él pueda cambiar o controlar, entonces la división entre el observador y lo observado ya no existe más, de modo que el observador ha eliminado instantáneamente dentro de sí la causa de conflicto y 
contradicción. Sin embargo, el hecho de la violencia permanece: sigo siendo violento por naturaleza, todo mi ser es violento y es puro desatino decir que una parte de mí es amable y afectuosa mientras que otra parte es violenta. La violencia implica división, contradicción, conflicto, estado de separación y falta de amor. Pero ahora he comprendido el hecho principal, o sea, que el observador es lo observado y, por lo tanto, ya no está más en conflicto con lo observado. Yo soy el mundo y el mundo es lo que soy; soy la comunidad y la comunidad es lo que soy...

Y después de observar, sigue existiendo el hecho de que soy violento, aun cuando pueda decir que yo y la violencia somos una sola cosa. Entonces, ¿qué he de hacer? Cuando observo que soy violento y veo muy claramente que el observador es esa violencia, entonces me doy cuenta de que no puedo hacer nada en absoluto, porque cualquier acción, ya sea positiva o negativa, sigue siendo parte de esa violencia» (Conversaciones con estudiantes, pp. 133-134).

Y aquí, cuando no es el yo el que observa ¿quién observa? La inteligencia:

«Preguntamos: ¿la mente se da cuenta de que el "yo" es la causa de este mal? La mente "emplee, si gusta, la palabra inteligencia" que ve el mapa completo de la violencia con todas sus intrincadas complejidades, que lo ve por medio de la observación, esta mente dice: Esa es la raíz de todo el mal» (La conciencia fragmentada, p. 181).

Quien ve es la inteligencia y es ella la que actúa inmediatamente. El yo nada puede «hacer» porque él es violencia y todo lo que haga es seguir fomentándola. Es la inteligencia quien hace salir de este círculo infernal. Por eso no es necesario «hacer de nuestra parte» sino dejar que la inteligencia actúe. Ésta se enfrenta con el hecho y encarándose completamente a él, éste desaparece. Al final es la inteligencia quien disuelve la violencia sin forzar nada ni echar mano de la fuerza de voluntad. Ella es quien disuelve nuestros problemas. Y ahí es donde hay que actuar con toda energía. O mejor dicho, poner esa energía en despejar el mapa interno de la violencia para que la inteligencia actúe. Por tanto, el problema es ser inteligente. Porque cuando la inteligencia marca el camino, ella actuará dondequiera que uno esté. Lo importante es estar imbuido de ella. Y ella actuará sobre la violencia esté uno dónde esté y sea uno lo que fuere: jardinero, cocinero o profesor. Esa inteligencia llenará de pasión y actuará sobre la violencia. Y no distorsionará ésta con ideales de no-violencia o de cualquier otra cosa; sino que se empleará a fondo en la erradicación de la violencia sin alterar la propia realidad.

Por eso Krishnamurti sondeando el tema del ver, le añade el matiz de la observación, dada la importancia de lo que nos traemos entre manos. La observación sería así una visión impregnada de inteligencia. Y precisando más ésta, se trata de una comprensión no precisamente «intelectual», sino integral. La comprensión intelectual es una mera intelección de las palabras sin que su sentido cale en el alma y comprometa el ser entero que es de lo que se trata. Y así se convierte más bien en un impedimento para la verdadera comprensión. Ésta compromete al ser entero y le hacer correr por la sangre de sus venas el sentimiento de la liberación de la violencia. La comprensión del proceso de destrucción y desorden de la violencia induce a un sentimiento de afecto y amor del que surge un nuevo orden de cosas. No olvidemos que para Krishnamurti la verdadera inteligencia va unida al amor, y que, operando aquélla, surge éste:

«Pero si comprende todo el proceso de la destrucción y el desorden, si lo estudia, no sólo en lo externo sino en usted mismo, entonces, como resultado de esa comprensión, de ese interés, de ese sentimiento de afecto, de amor, surge un orden por completo diferente. Pero si no comprende, si meramente se rebela, ése es el mismo patrón repetido una, otra y otra vez, porque nosotros somos siempre los mismos seres humanos» (Krishnamurti y la educación, p. 71). 
En definitiva, la comprensión de la causa de la violencia da lugar a la indulgencia y la bondad. El amor y la comprensión advienen gracias a un constante estado de alerta.

Y, por último, se detiene ahora Krishnamurti en desmenuzar ese estado de alerta de la inteligencia que es lo que, a fin de cuentas, disuelve la violencia. Este estado de alerta tiene que cuidar que la mente no sea engañada por ideales que eludan la violencia. Y el problema es que se ha dedicado durante siglos y siglos a elaborar ideales como algo que vale la pena.

Para poder comprender nuestra violencia tiene que haber una constante percepción alerta, la cual hará que afloren a superficie las causas de la violencia; al verlas sin identificarnos con ellas, la inteligencia las superará.

Pero también en la atención como en otros procesos, Krishnamurti señala un camino negativo, no positivo. Es una línea que se dibuja constantemente a lo largo de su pensamiento. Cuando estamos ante nuestra violencia, vemos y comprendemos inteligentemente que la represión, el control y el escape no resuelven el problema y por tanto los descartamos:

«Ahora bien, tengo esta inteligencia que ha surgido al comprender la futilidad de la represión, del escape, del tratar de imponerme. Con esta inteligencia estoy investigando y observando la crueldad. Me doy cuenta de que para observarla debe haber una gran dosis de atención y que para tener esa atención debo ser muy cuidadoso con mi inatención. De manera que mi interés es darme cuenta de la inatención. ¿Qué quiere decir eso? Si trato de practicar la atención, se torna mecánica, estúpida y sin sentido; pero si me vuelvo atento, o me doy cuenta de mi falta de atención entonces comienzo a descubrir cómo surge mi atención. ¿Por qué no estoy atento a los sentimientos de otros, a mi modo de hablar, de comer, a lo que la gente dice y hace? Al comprender el estado negativo, llegaré a lo positivo, lo cual es atención. Estoy, pues, examinando, tratando de comprender cómo surge esa inatención» (El vuelo del águila, p. 129).

Es decir, la atención no se consigue de manera directa, sino indirecta o negativa: es dándome cuenta de mi inatención como surge la atención. No a la inversa. ¿Cómo es posible darse cuenta de la inatención de modo tan completo que ésta se convierta en atención? Cuando nos demos cuenta de que nuestra energía la gastamos en la inatención, es decir, en superficialidades y minuciosidades. Cuando seamos conscientes del derroche de energía en estas nimiedades, entonces ésta se pondrá entera al servicio de la atención. Y con ella se aborda adecuadamente el problema de la violencia:

"¿Qué ocurre cuando concedemos atención completa a esa cosa que llamamos violencia? La violencia no es tan sólo lo que separa a los seres humanos a causa de la creencia, el condicionamiento y demás, sino también lo que se manifiesta cuando buscamos la seguridad personal, o la seguridad del individuo, por medio del patrón social. ¿Pueden ustedes mirar esa violencia con atención completa? Y cuando la miran así ¿qué ocurre? Cuando concedemos atención completa a algo "al estudio de la historia o las matemáticas, al mirar a nuestra esposa o a nuestro marido”, ¿qué ocurre? No sé si alguna vez lo han examinado; es probable que la mayoría de nosotros jamás haya prestado atención completa a nada, pero cuando lo hacen, ¿qué ocurre? Señores, ¿qué es la atención? Por cierto, cuando prestan atención completa hay preocupación por el otro, y no pueden preocuparse por el otro si no sienten afecto, amor. Y cuando conceden una atención que contiene afecto, ¿hay violencia? ¿Entienden? Formalmente, uno ha condenado la violencia, ha escapado de ella, la ha justificado, ha dicho que es natural. Todas estas cosas son inatención. Pero cuando uno presta atención a eso que ha llamado violencia, atención que contiene preocupación, afecto, amor, ¿dónde hay espacio para la violencia?»(El libro de la vida, 22 de junio). 
Así pues la atención ha dado lugar a la inteligencia, el amor y el afecto y no ha quedado espacio interno para la violencia. Este ha sido el proceso. Encarar la violencia eliminando la barrera que nos separaba de ella. Esa barrera era el yo que se excluía de ella. Ahora veo y siento que yo soy violencia. Miro ésta, la veo, la observo con toda mi alma, con todo mi ser y mi cuerpo. Y la observo en silencio sin intención del expulsarla, cambiarla o huir de ella. Entonces esa observación se hace inteligencia que ve todo el espectro de la violencia: causas, formas y estructura. Pero esa inteligencia que no es yoica ni está segregada de la vida y la realidad, aporta su energía que es amor y compasión, expulsando del territorio interno la violencia y convirtiendo éste en un paraíso.

\section{BiBLIOGRAFÍA}

- Krishnamurti, Comentarios sobre el vivir, primera parte, Buenos Aires, Kier 1994

- Conversaciones con estudiantes, Buenos Aires Kier, 1994.

- Diario II, México, Sudamericana 1991

- El libro de la vida, Madrid, Edaf 1996.

- El vuelo del águila, Barcelona, Paidós 1986.

- Krishnamurti y la educación, Barcelona,Edhasa 1991.

- La conciencia fragmentada, Buenos Aires, Kier 1994.

- La crisis del hombre, Buenos Aires, Kier 1989.

- La libertad primera y última, Barcelona Kairós 1996.

- Limpia tu mente, Barcelona, Ed Martínez Roca 1999.

- Mas allá de la violencia, Barcelona, Edhesa 1991.

- Obras Completas I, Buenos Aires, Kier 1994.

- Obras Completas III, Buenos Aires, Kier 1997.

- Pedagogía de la libertad, Barcelona, Oasis 1996.

- Principios del aprender, Barcelona, Edhesa1988

- Reflexiones sobre el ser, Buenos Aires, Errepar 1999.

- Clavier, A., Caminar con Krishnamurti. Buenos Aires: Kier, 1989.

- JAYAKAR, P., Krishnamurti: Biografía. Buenos Aires: Kier, 1989.

UNED

Manuel Suances Marcos

asuances@fsof.uned.es

[Artículo aprobado para su publicación en noviembre de 2013] 